\title{
DERMATOPHYTOSIS CAUSED BY MICROSPORUM CANIS AND MICROSPORUM GYPSEUM IN FREE-LIVING BRADYPUS VARIEGATUS (SCHIZ, 1825) IN THE STATE OF PERNAMBUCO, BRAZIL
}

\author{
Gileno Antônio Araújo Xavier'; Leonildo Bento Galiza da Silva²; Davi Rubem da Silva ${ }^{3}$; \\ Rodolfo de Moraes Peixoto ${ }^{4 *}$; Gileno Câmara Lino" ${ }^{4 *}$; Rinaldo Aparecido Mota ${ }^{2 *}$ \\ ${ }^{1}$ Departamento de Morfologia e Fisiologia Animal, Universidade Federal Rural de Pernambuco, Recife, PE, Brasil; \\ ${ }^{2}$ Departamento de Medicina Veterinária, Universidade Federal Rural de Pernambuco, Recife, PE, Brasil; ${ }^{3}$ Programa de \\ Pós-Graduação em Ciência Veterinária, Universidade Federal Rural de Pernambuco, Recife, PE, Brasil; ${ }^{4}$ Recife, PE, Brasil. \\ Submitted: October 03, 2007; Returned to authors for corrections: January 08, 2008; Approved: July 13, 2008.
}

\begin{abstract}
Three cases of dermatophytosis in free living brown-throated three-toed sloths (Bradypus variegatus) in the Zona da Mata, North of Pernambuco State, Brazil, were studied. Two animals presented areas of alopecia on the pelvic member and thorax and one animal on the pelvic member only. The three animals presented scabs. Hair and scabs samples were submitted to microscopical examination after treatment with a $30 \% \mathrm{KOH}$ and cultivated in Mycosel Agar. The direct examination indicated the presence of arthrospores in the hair. Colonies grown after seven days of culture were confirmed as Microsporum based on examination of the structure of the macroconidia. This is the first observation of dermatophytosis caused by Microsporum canis and Microsporum gypseum in free living sloths in the State of Pernambuco.
\end{abstract}

Key-words: Microsporum canis, Microsporum gypseum, Bradypus variegatus, dermatophytosis, sloths.

\section{INTRODUCTION}

Microorganisms present in the wild, following an evolutionary process of millions of years, are well adapted to the environment, rarely representing a threat to the animal population. The infectious agents can be considered normal and essential components of the environment, and should be preserved along with other elements of the ecosystem $(1,2)$. In the absence of environmental changes, therefore, the role of infectious diseases as a native population-controlling factor is probably significant.

In recent years, the expansion of the human population and the increase of domesticated animals have created a straight path for infecting organisms uncommon to the wild environment (1). When discussing disease transmission among different species, it is convenient take three groups into consideration: a) wild fauna; $b$ ) domestic fauna; and c) human population. In this context, the involvement of different interests - conservationists, economists, and public health officials, becomes evident (3).

Sloths are arboricole mammals that live, feed and reproduce on the top of trees and can hold in feces and urine for a week. They descend the trees to eliminate the feces, using their tails to dig a hole in the ground; afterwards they urinate on the top of the hold and cover it with leaves, and with a typical leg movement climb back up the tree. The whole process of descent, defecation and return to the tree takes approximately 30 minutes (4).

Dermatitis occurs often in these animals, and the diagnosis, treatment and prophylactic orientation vary according to the etiology of the process (5).

Dermatophytosis is an infection of keratinized tissues, nails, fur and cornea extract, caused by different species from the genera Microsporum, Trichophyton and Epidermophyton. Those dermatophytes are the only fungi capable of invading

*Corresponding Author. Mailing address: Departamento de Medicina Veterinária, Universidade Federal Rural de Pernambuco, R. Dom Manoel de Medeiros, s/n - Dois Irmãos, Recife, PE, Brasil. 52171-900. E-mail: canjani_ch@hotmail.com

\# Médico Veterinário, autônomo. 
and residing in keratinized tissues. They are transmitted by contact with fur and dandruff, either infected or containing fungal particles, originating either from the animals, the environment or fomites. Geophilic dermatophytes, such as $M$. gypseum, usually inhabit the soil, where they decompose into keratinized debris. The zoophilics, such as $M$. canis, have adapted to animals and are found in the soil only rarely (6).

Microsporum canis is the etiologic agent most frequently associated with dog and cat dermatophytosis. Human infection through contact with animals is fairly common. Microsporum canis has also been found associated with other species: ruminant, equine, swine, primate, large felines, and others. It is considered highly pathogenic to canines, rodents and mustelids $(7,8)$. In Brazil, the only report of this type of infection in sloths B. tridactylus was obtained in the city of Belém, PA by Silva et al. (9). M. gypseum produces lesions that are generally scabby and almost always isolated. It can be found on dogs, cats, horses, steers and wild animals (7).

Due to the lack of studies involving the sanitizing aspects of free-living sloths (Bradypus variegatus) in Brazil, the main objective of this study was to report the incidence of dermatophytosis caused by $M$. canis or M. gypseum in the aforementioned species in the state of Pernambuco, Brasil.

\section{MATERIALAND METHODS}

Three adult, male sloths from the $B$. variegatus species were examined (Fig. 1), originated from the towns of Itamaracá and Abreu e Lima, Pernambuco, Brazil. The animals showed skin lesions with patchy fur hair, alopecia and rough scabs on the pelvic members and internal portion of the thighs with lesions of various sizes. Only two of the animals had lesions on the thoracic members, lesions of approximately $5.0 \mathrm{~cm}$ of diameter around the distal extremity. The macroscopic aspect of the lesions demonstrated on Fig. 2 illustrates the findings for all cases.

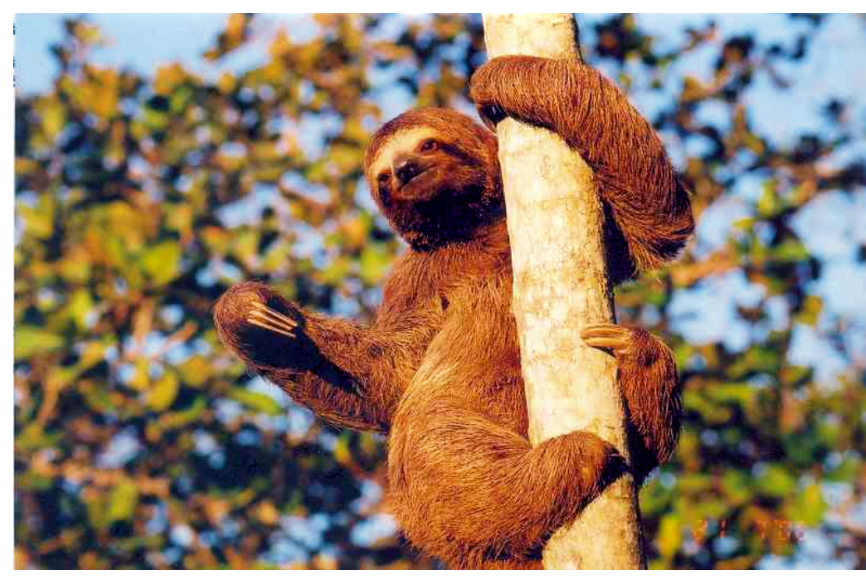

Figure 1. Bradypus variegatus.

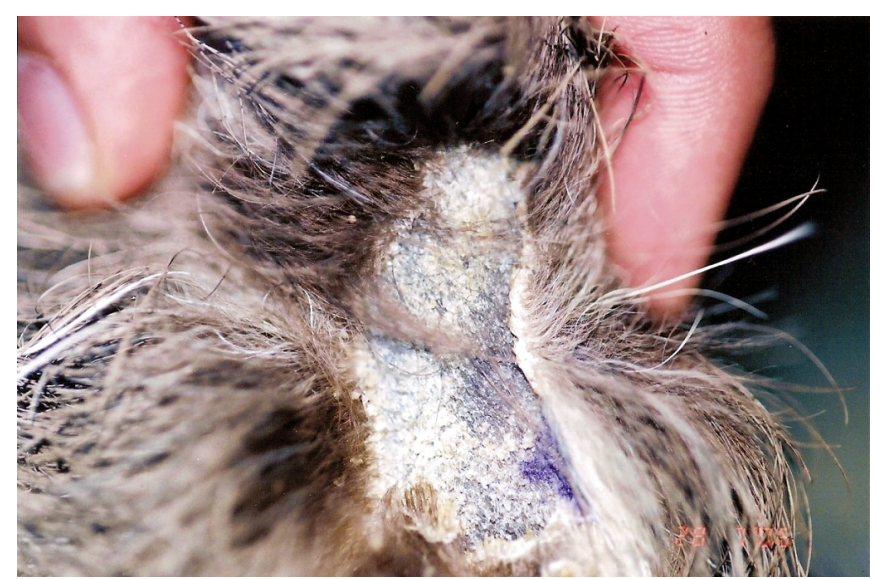

Figure 2. Dermatophytosis in B. variegatus: circumscribed area of alopecia and desquamation of the pelvic member.

The animals were physically restrained and the hair and scabs were collected using a scalpel to scrape the skin. Part of the collected sample was used to make a direct examination, being clarified with a $30 \%$ potassium hydroxide solution on a glass slide. Later, this specimen was observed with an optical microscope $(40 \mathrm{x})$ to look for fungal structures (artrospores). Another part of the sample was cultivated in Mycosel Agar (OXOID) and incubated at room temperature for a couple of weeks. The diagnostics was reached by considering the type of lesion, the direct examination and the fungal isolation, taking into consideration fungal growth and microscopic morphology of the conidia (macro and microconidium) according to Cruz (7).

\section{RESULTS AND DISCUSSION}

Considering the dermatologic clinical state presented by the animals, the presence of patchy fur hair and scabs indicated dermatomycosis. The direct examination demonstrated the presence of ecto- and endothrix arthrospores, suggestive of dermatophyte fungi.

In Brazil, studies reporting the presence of these fungi infecting sloths are rare, with the exception of the considerations made by Silva et al. (9) describing clinical findings of tonsuring alopecia caused by $M$. canis to $B$. tridactylus, indicating the first clinical finding with this agent on the afore mentioned species. The clinical and microbiological findings observed during the present study are similar to the ones reported by those authors. Diniz and Oliveira (10) studied fifty-one sloths from the São Paulo zoo in a study over twenty year period and reported ectoparasites in four animals (4.9\%), although the authors did not describe the genera of ectoparasites identified.

It is noteworthy to mention that during the present study, the three animals captured presenting skin lesions (100.0\%) were positive for the genera Microsporum, emphasizing the 
importance of these dermatophytes on dermatomycosis in this species.

After seven days, the cultures revealed the presence of cotton-like white colonies, with yellowish central area and radial ridges, with the reverse of the colonies being yellowish. This agrees with the description of Van Cutsem and Rochette (8) for $M$. canis, as was found in our first case. Colony growth with pulverulent texture and color variation from yellowish-brown to light-brown, with the reverse of the colonies being light yellow characterizing M. gypseum as described by Scott et al. (6), was observed in the second and third cases.

The colony microscopic examination, performed using the cotton blue technique, revealed echinulate macroconidia forming a spiral shape characteristic of M. canis in the first case, and in the second and third cases helical macroconidia with echinulate walls with up to six cells, characteristic of M. gypseum.

In domesticated species, especially in cats, infection by $M$. canis is usually self-limiting, confirming the tolerance of this species to this type of dermatophyte, and acting as an asymptomatic carrier for other animals from the same and from other species (11).

In other species, this fungus can cause lesions due to its lack of adaptation and also due to the production of toxic metabolites that causes skin irritation and alopecia, favoring mostly secondary bacterial infections usually followed by suppuration (7).

Although it is not possible to confirm thoroughly the source of the infection, it is strongly believed that those sloths, because of their arboreal habitation, have been infected through the contact with the infected hair from other animals, since the $M$. canis is zoophilic and remains viable in the environment for over 18 months $(6,12)$. Another possibility to be considered would be the fact that sloths need to climb down a tree to defecate, urinate or to move around, thus becoming more vulnerable when in contact with the fungus in the soil, since $M$. gypseum is a geophilic dermatophyte and a natural inhabitant of the soil (6). It is also plausible to consider that contact with other arboreal animals, or with their hair on the tree branches, could present a source of contamination.

This is the first report of dermatophytosis in free-living Bradypus variegatus sloths in the state of Pernambuco, Brazil. It should be noted that, due to their similarity, it is not possible to differentiate macroscopic lesions caused by M. canis and $M$. gypseum, unless cultures from hair and scabs are examined.

\section{RESUMO}

\section{Dermatofitose por Microsporum canis e Microsporum gypseum em Bradypus variegatus (Schiz, 1825) de vida livre no estado de Pernambuco, Brasil}

Foram estudados três casos de dermatofitose em preguiçasde-garganta-marrom (Bradypus variegatus) de vida livre na
Zona da Mata, Norte do Estado de Pernambuco, Brasil. Dois animais apresentavam áreas de alopecia nos membros pélvicos e torácicos e um apenas no membro pélvico. Em todos os animais foi observada a presença de crostas. As amostras de pêlos e crostas foram submetidas ao exame microscópico direto com $\mathrm{KOH}$ a $30 \%$ e cultivo em Ágar Mycosel. Ao exame direto foram observados artrosporos nos pêlos e sete dias após o cultivo foram observadas colônias sugestivas do gênero Microsporum, confirmadas através da observação da estrutura dos macroconídeos. Trata-se do primeiro relato de ocorrência de dermatofitose por Microsporum canis e Microsporum gypseum em preguiças de vida livre no Estado de Pernambuco.

Palavras-chave: Microsporum canis, Microsporum gypseum, Bradypus variegatus, dermatófitos, preguiças.

\section{REFERENCES}

1. Jones, D.M. (1982). Conservation in relation to animal disease in Africa and Asia. In: Edwards, M.A., Mc Donnel, V. (eds). Animal disease in relation to animal conservation. The Zoological Society of London, Academic Press, London, England, p. 287-297.

2. De Vos, V. (1991). The control of infectious diseases and parasites in the National Parks of South África. World Veterinary Congress, Rio de Janeiro, RJ, p. 21.

3. Henderson, W.M. (1982). The control of disease in wildlife when a threat to man and farm livestock. In: Edwards, M.A., Mc Donnel, V. (eds). Animal disease in relation to animal conservation. The Zoological Society of London, Academic Press, London, England, p. 271-285.

4. Montgomery, G.G. (1983). Bradypus variegatus (Perezoso de tres dedos, tree-toed sloth). In: Jansen, D.H. (ed). Costa Rican natural history. The University of Chicago Press, Chicago, USA1983, p. 453-455.

5. Costa, E.O.; Diniz, L.S.M.; Carvalho, V.M.; Coutinho, S.D.; Benites, N.R. (1995). Dermatoses observadas no homem e animais de laboratório e silvestres em São Paulo. Levantamento retrospectivo. Arq. Bras. Med. Vet. Zoot., 47, 601-607.

6. Scott, D.W.; Miller, J.R.; Griffin, W.H. (1996). Dermatologia de pequenos animais. Interlivros, Rio de Janeiro, RJ.

7. Cruz, L.C.H. (1985). Microbiologia veterinária. Itaguaí / UFRRJ, Rio de Janeiro, RJ.

8. Van Cutsem, J.; Rochette, F. (1991). Mycoses in domestic animals. Janssen Research Foundation, Beerse.

9. Silva, M.B.; Moreira, S.B.; Costa, P.F.; Justino, C.H.S.; Doimo, G.M.; Silva, J.P.; Costa, A.M.; Salgado, C.G. (2002). Isolamento de Microsporum canis em alopécia tonsurante de Preguiça-deBentinho (Bradypus tridactylus). VI Congresso e XI Encontro da associação Brasileira de Veterinários de Animais Selvagens, Vitória, ES, p. 247.

10. Diniz, L.S.M.; Oliveira, P.M.A. (1999). Clinical problems of sloths (Bradypus sp. and Choloepus sp) in captivity. J. Zoo. Wildl. Med., 30, 76-80.

11. Greene, C.E. (1990). Infectious diseases of the dog and cat. W.B. Saunders Co., Philadelphia, USA.

12. Carter, G.R.; Chengappa, M.M. (1991). Essentials of veterinary bacteriology and mycology. Lea and Febiger, Philadelphia, USA. 